\title{
MOWA SYMBOLI I MOWA FORM. EDGAR WIND I LEO STEINBERG PRZECIW ZEŚWIECCZANIU OSTATNIEJ WIECZERZY LEONARDA DA VINCI
}

Robert Pawlik

Uniwersytet Kardynała Stefana Wyszyńskiego

Pamięci Margaret Wind

And so it comes to pass that though he handles sacred subjects continually, he is the most profane of painters.

Walter Pater o Leonardzie da Vinci (1869)

Czytając rozważania Edgara Winda na temat Ostatniej Wieczerz $y$, warto pamiętać, że mamy do czynienia z radiową pogadanką. Wiosną 1952 roku niemiecki historyk zarejestrował dla radia BBC trzy audycje poświęcone Leonardowi da Vinci. Ich transkrypcja, ogłoszona bez zgody autora w piśmie słuchaczy „The Listener” (Wind 1952a: 705-706, 1952b: 747-748, 1952c: 787-788), to jedyna zachowana wypowiedź Winda na temat artysty, któremu poświęcił wiele naukowej uwagi, ale żadnej publikacji1 ${ }^{1}$. Znaczenie drugiej z tych audycji, dotyczącej malowidła z dominikańskiego refektarza przy kościele Santa Maria delle Grazie w Mediolanie, polega na tym, że w krótkiej wypowiedzi autor zakwestionował dominującą wykładnię tego dzieła, jaka obowiązywała w studiach nad nim od początku XIX wieku. Ten „najpopularniejszy obraz w całej włoskiej sztuce” (Wölfflin 1931: 23) czy „bodaj największe arcydzieło sztuki malarskiej, jakie kiedykolwiek powstało" (Burckhardt 1939: 115) miało ukazywać moment, w którym Chrystus w Wieczerniku wypowiedział słowa: „Jeden z was mnie zdradzi”, oraz psychologiczny wstrząs, jaki słowa te wywołały w zgromadzonych uczniach. Wind zaproponował interpretację, w świetle której symbolika obrazu jawi-

\footnotetext{
1 Twórczość Leonarda da Vinci była wielokrotnie przedmiotem wykładów Edgara Winda. Wiadomo, że w 1941 roku wygłosił on prelekcję o Ostatniej Wieczerzy na uniwersytecie w Yale (por. Sears 2000: XXVIII). Poświadczone są sześciowykładowe kursy o Leonardzie prowadzone w okresie pracy Winda na Uniwersytecie w Oksfordzie w latach 1956, 1959, 1962 i 1966. W roku 1960 historyk mówił o Leonardzie również w ramach Royal Institution Lecture w Londynie (por. Archiwum Edgara Winda w Oksfordzie).
} 
ła się jako znacznie bardziej złożona i wiązała się nie tylko z psychologia, ale przede wszystkim $z$ teologia.

W niniejszym szkicu chciałbym prześledzić jeden wątek z ogromnej dyskusji, która toczyła się wokół symboliki Ostatniej Wieczerzy. Bezpośrednim celem będzie osadzenie stosunkowo mało znanego odczytania zaproponowanego przez Edgara Winda w szerszym kontekście dziejów interpretacji mediolańskiego obrazu. Dla uwypuklenia specyfiki tego odczytania, wiążącego się z Windowską koncepcją symbolu i zadań historii sztuki, zestawiam je z wyrastająca z odmiennej metodologii, lecz prowadząca do podobnych wniosków, lektura zaproponowana przez Leo Steinberga (która ze swej strony stanowi rozwinięcie pracy polskiego badacza - Jana Bołoza-Antoniewicza). Głównym celem mego szkicu jest pokazanie na konkretnym przykładzie tendencji sekularyzacyjnej w odczytywaniu dzieła Leonarda oraz - czemu poświęcona jest ostatnia część pracy - wysiłków zmierzających do przywrócenia symbolice teologicznej miejsca w studiach nad sztuką odrodzeniowa.

\section{/// Goethe: świecki dramat zdrady}

Umiejętność ukazywania ludzkich uczuć, przedstawiania postaci, których emocje łatwo daja się odczytać, zawsze uchodziła za wyróżnik sztuki Leonarda. Jednak tłumaczenie mediolańskiego Cenacolo wyłącznie w kategoriach psychologicznych, tj. jako ilustracji „duchowego szoku” spowodowanego słowami Jezusa o zdradzie, wydaje się stosunkowo świeżej daty $^{2}$. Najprawdopodobniej po raz pierwszy zaproponował je włoski malarz Giuseppe Bossi, któremu na początku XIX wieku powierzono zadanie sporządzenia olejnej kopii mediolańskiego dzieła i który przy tej okazji przygotował jego nowatorską monografię. W studium Del Cenacolo di Leonardo da Vinci dowodził on, iż wypowiedziana zapowiedź zdrady podczas ostatniego spotkania Chrystusa z uczniami stała się dla artysty pretekstem do namalowania dzieła nie tyle obliczonego na ,zdobycie uznania u ludzi religijnych”, ile przeznaczonego dla „ludzi zdolnych odczuwać emocje, niezależnie od czasu i wyznania" (Bossi 1810, por. Steinberg 2001: 198).

Interpretacja Bossiego zyskała ogromną popularność dzięki temu, że kilkanaście lat później, w 1817 roku podją ją i rozwinął Johann Wolfgang

\footnotetext{
${ }^{2}$ Obwieszczenie zdrady na obrazie Leonarda dostrzegł już Luca Pacioli we wstępie do traktatu De divina proportione z 1498 roku: „Niepodobna wyobrazić sobie większego skupienia niż to, z jakim apostołowie przyjmują obwieszczenie prawdy niesłychanej: Unus vestrum me traditurus est. Z ich zachowania i gestów wynika, że mówią między soba, jeden do drugiego, a ten do trzeciego, wielce poruszeni i zdumieni” (cyt. za Nicholl 2006: 366).
} 
von Goethe. Esej Joseph Bossi über Leonardo da Vinci Abendmahl zu Mailandjeden z najbardziej poczytnych szkiców o sztuce, jakie wyszły spod pióra niemieckiego poety - przez ponad stulecie był podstawowym punktem odniesienia dla wszystkich zabierających głos na temat Leonardowego malowidła. W istocie szkic ten stanowił omówienie książki Bossiego, przy czym kunszt prozy Goethego wydatnie wzmocnił perswazyjność argumentów malarza.

Goethego, wielkiego admiratora sztuki Leonarda (Goethe 1817: 4984) ${ }^{3}$, w Ostatniej Wieçeræy zachwyca przede wszystkim zdolność ukazywania gwałtownych uczuć:

Przenieśmy się w to miejsce, pomyślmy o pełnym powagi, niczym niezakłóconym spokoju panującym w monastycznym refektarzu, wówczas będziemy podziwiać artystę, który potrafił tchnąć w swój obraz potężne emocje, pełen namiętności ruch, czym zbliżył się do natury najbardziej, jak to możliwe, wprowadzając zarazem kontrast między rozgrywającą się sceną a otaczającymi ją realiami. Środkiem pobudzającym, którym artysta zburzył sakralny spokój wieczornego posiłku, sa słowa Mistrza: „Jeden z was mnie zdradzi!”. Ich wypowiedzenie wtrąca wszystkich biesiadników w stan głębokiego poruszenia; on zaś tylko skłania głowę i opuszcza wzrok; cała postawa, ruch ramion, ręce, wszystko powtarza z niebiańską rezygnacją nieszczęsne słowa, które dodatkowo wzmacnia milczenie: Tak jest, nie inaczej! Pośród was jest ten, który mnie zdradzi. [...] Doskonały zabieg, którym w dużej mierze Leonardo ożywił swój obraz, to ruch rak; tylko Włoch był w stanie to wymyślić. W jego narodzie całe ciało jest naznaczone życiem, wszystkie członki uczestniczą w wyrażaniu uczuć, namiętności, a nawet myśli. Różnorakim ułożeniem i ruchem rąk potrafi on wyrazić: Co mnie to obchodzi! - Podejdź! - To jest łotr, uważaj na niego! - Nie pożyje już długo! - Tu tkwi sedno! Na to, moi słuchacze, zwróćcie baczną uwagę! Ta narodowa specyfika nie mogła ujść uwagi Leonarda, w najwyższym stopniu wyczulonego na wszystko, co charakterystyczne; w tym właśnie obraz Leonarda jest wyjątkowy i można te ruchy rąk kontemplować w nieskończoność. Wygląd postaci oraz ich ruchy doskonale sobie odpowiadaja, a łatwo uchwytne dla oka

\footnotetext{
${ }^{3}$ „Wieczorem wybrałem się na spacer z jednym rodakiem i spieraliśmy się, komu przyznać pierwszeństwo: Michałowi Aniołowi czy Rafaelowi. Ja trzymałem stronę pierwszego, on drugiego. Pogodziliśmy się, chwaląc zgodnie Leonarda da Vinci” - 31 lipca 1787 roku (Goethe 1980: 330).
} 
zgodności i przeciwstawienia członków ciała zasługują na najwyższą pochwałę (Goethe 1939: 54).

W innym miejscu tego szkicu Goethe dodaje:

[...] na obrazie Leonardo przedstawił trzynaście postaci, od młodzieńca po starca: jedną w cichej rezygnacji, jedną przerażoną, jedenaście pobudzonych i zbulwersowanych myślą o zdradzie w rodzinnym kręgu. Widać tutaj zachowania najłagodniejsze i najbardziej stosowne, aż po najgwałtowniejsze i roznamiętnione (Goethe 1939: 75).

Krótko mówiąc, zdaniem Goethego mediolański obraz przedstawia dwanaście różnych reakcji czy też „odpowiedzi” na przepowiednię Jezusa. Reakcje te wypowiedziane sa głównie w typowym dla Włochów języku gestów i składają się na bogaty repertuar możliwych konfiguracji, ale także katalog emocji: od gwałtowności i namiętności po rezygnację. W swym eseju Goethe wyraźnie przykłada do analizowanej sceny kategorie zaczerpnięte z poetyki dramatu - dostrzega w niej klasyczną jedność czasu, miejsca i akcji. Kunszt Leonarda objawia się zatem w umiejętności zredukowania złożonej opowieści ewangelicznej do jednego momentu kulminacyjnego, chwili najwyższego psychologicznego napięcia, co stawia florenckiego artystę $\mathrm{w}$ jednym rzędzie z dramaturgiem takim jak Szekspir4. Prowadzi to Goethego do wniosku, że religijne malowidło z Mediolanu przedstawia w gruncie rzeczy całkowicie świecką tragedię zdrady.

Za równie ważne dokonanie Leonarda poeta uznaje przesunięcie akcentu z wydarzeń zewnętrznych - tego wszystkiego, co zdarzyło się podczas pożegnalnego posiłku uczniów z Chrystusem - na to, co dokonywało się we wnętrzu każdego z biesiadników. Obserwowane gesty stanowią oznakę bogactwa życia wewnętrznego prezentowanych postaci. Różnorodność ekspresji ciała, twarzy i rąk świadczyła o rozpiętości i złożoności duchowego życia człowieka. Prawdziwym celem florenckiego malarza i pretekstem do namalowania tego obrazu okazuje się więc chęć uzewnętrznienia w medium plastycznym „stanów duszy” czy życia psychicznego.

Wykładnię tę historycy sztuki i komentatorzy powtarzali i powtarzają mniej lub bardziej dosłownie, niekiedy tylko radykalizując retorykę lub

${ }^{4} \mathrm{Na}$ podobieństwo Leonarda i Szekspira wskazywano wielokrotnie (np. Pater 1998: 89, Dvořák 1974: 395). 
wnioski ${ }^{5}$. Na przykład Bernard Berenson „czuł odrazę do Ostatniej Wieczerzy Leonarda da Vinci” właśnie z powodu roznamiętnienia tej sceny. Jego zdaniem owa wybujała i dobitna mowa gestów pasowałaby bardziej do rozgorączkowanej ciżby na targowisku w Neapolu niż do uroczystościreligijnej ${ }^{6}$. Natomiast Georg Simmel w szkicu z 1905 roku jeszcze mocniej uwypuklił fakt zindywidualizowania postaci oraz oddania głębi życia wewnętrznego. Podkreślał on, że Cenacolo to pierwszy obraz w tradycji scen zbiorowych, w którym każda z postaci wyróżnia się wyglądem, zachowaniem i charakterem $-\mathrm{z}$ tego powodu zbędne stały się tu nie tylko podpisy, ale nawet typowe atrybuty, które wcześniej malarze dodawali dla ułatwienia identyfikacji poszczególnych apostołów. Jednak dla niemieckiego socjologa interpretacja mediolańskiego obrazu wznosi się na wyższe piętro: chodzi w nim o przedstawienie pełni osobowości i wolności. Fakt, że zaledwie jedno wypowiedziane zdanie, tj. jeden zewnętrzny bodziec, mógł przełożyć się na tak wiele różnych reakcji - czyli został odebrany przez każdego z uczniów indywidualnie - potraktował Simmel jako jawny dowód swobody ludzkiej psyche wobec świata zewnętrznego. Jednym słowem Ostatnia Wieczerz̨a okazuje się celebracją autonomii ludzkiego ducha, której odkrycie stanowi główne dokonanie nowoczesności: „Po raz pierwszy w grupowym obrazie osiagnięto tu ową pełną wewnętrzną wolność osobowości, która była zwycięstwem renesansu nad skrępowaniem człowieka średniowiecznego i dała hasło czasom nowożytnym - wolność, dla której cały świat i jego dzieje są tylko środkiem i podnietą, dzięki której Ja staje się sobą" (Simmel 2006: 151).

\footnotetext{
${ }^{5} \mathrm{Z}$ wielu przykładów wybieram cztery reprezentatywne: „Leonardo ogranicza się do pokazania psychologicznego momentu wzburzenia, które wywołane zostało słowami Chrystusa. Jakby grom uderzył. I właśnie sposób, w jaki zareagowali wierni oraz zdrajca, jest właściwym tematem przedstawienia” (Dvořák 1974: 392). „Zbawiciel sam jest spokojny, ze spuszczonymi oczyma, a w milczeniu jego tkwi jakby powtórzenie: tak jest, jeden jest między wami, który mię zdradzi. [...] Słowa mistrza uderzyły jak piorun. Burza uczuć rozpętała się wokoło” (Wölfflin 1931: 23-26). „Ostatnia Wieczerza Leonarda [...] jest przede wszystkim wielkim dramatem psychologicznym. Chrystus powiedział przed chwila «Jeden spośród was Mnie zdradzi» i słowa te wywołały gwałtowne poruszenie wśród Jego uczniów [...]. Subtelnie zróżnicowane reakcje psychiczne poszczególnych apostołów - zdziwienie, zdumienie, przerażenie, cichy smutek, wattpliwości, ciekawość, gniew, oburzenie - znajduja wyraz w mimice dwunastu twarzy i w gestach dwudziestu czterech rak. [...] Jedynie Chrystus, choć z pewnością silnie poruszony wewnętrznie, na zewnątrz jest całkowicie spokojny. Dłonie rozłożył szeroko, jakby potwierdzając w ten sposób wypowiedziane przed chwilą słowa" (Wallis 1961: 11). „To pewnie najbardziej dramatyczny moment w całej Ewangelii [...]. Wypowiadając to swoje: «Jeden z was mnie zdradzi», Jezus wrzuca granat do wody [...]. Odpala dwunastojęzyczny, dwudziestoczteroręki wybuch: "Chyba nie ja?»" (Mikołajewski 2014: 16).

${ }^{6}$ „As a boy I felt repulsion for Leonardo's Last Supper. The faces were uncanny, their expressions forced, their agitation alarmed me. They were the faces of people whose existence made the world less pleasant and certainly less safe" (Berenson 1916: 1). Zob. także Kasperowicz 1997.
} 
$\mathrm{Na}$ wizerunek Leonarda - prekursora „ery jednostki”, w której indywiduum uwalnia się od średniowiecznego dyktatu ducha grupowego - nałożyło się wyobrażenie Leonarda jako artysty-naukowca, który antycypuje narodziny nowoczesnej nauki i techniki. W ten sposób Ostatnia Wieczerz̨a, owa „perła sztuki nowoczesnej” (Burckhardt 1992: 115), była nieustająco opisywana w kategoriach konstytutywnych dla nowoczesnej samoświadomości: indywidualizmu, wewnętrzności, osobowości, wolności, a także świeckości ${ }^{\dagger}$.

\section{/// Edgar Wind: wymowność symboli}

Edgar Wind w swoim wystapieniu wyraźnie stawia sobie za cel skorygowanie psychologizującego podejścia do mediolańskiego obrazu, które jednoznacznie kojarzy on z Goethem (Wind 2015a: 84). Jest przekonany, że akcent $w$ malowidle $z$ przykościelnego refektarza pada nie tylko na tajemnicę ludzkiej psyche, ale przede wszystkim na religijne misterium ofiary. Punktem wyjścia swej analizy czyni postać Chrystusa, w której Goethe dojrzał jedynie „cichą rezygnację”, a przez to osobę stosunkowo niewiele wnoszaca do dramaturgii sceny. Tymczasem dla Winda odgrywa On na obrazie rolę kluczowa, ponieważ „ostatecznie wszystkie postaci niejako zbiegają się w Chrystusie, i gestach Jego obu rąk" (Wind 2015a: 90)

Decydujące dla tego odczytania sa - całkowicie pominięte przez Goethego - rozłożone na stole dłonie Chrystusa, które wykonuja „dwie przeciwstawne, a nawet sprzeczne czynności”. Wind dostrzega w nich symbol ofiary czy dialektyki daru eucharystycznego. Dłoń po prawej stronie otwarta jest jakby w geście dawania, dłoń po lewej „wykonuje gest chwytania czy ujmowania" (Wind 2015a: 87). Obie ręce wyznaczaja dwie strony obrazu: prawa ,pozytywną”, stronę daru, i lewą „negatywną”, stronę utraty. Otwarta dłoń komunikuje ideę daru, w myśl tego, że podczas Ostatniej Wieczerzy Chrystus ofiarował siebie jako „pokarm zbawienia”. Otwartej dłoni Jezusa odpowiadają postawy i gesty rąk uczniów znajdujących się po prawicy Chrystusa: ekstatyczna reakcja św. Jakuba i Tomasza na dar zbawienia oraz pozy i dłonie św. Mateusza, Tadeusza i Szymona, ułożone w geście przyj-

\footnotetext{
7 Zob. także: Leonardo the Harbinger of Modernity (Turner 1993: 100-131). W pierwszej z audycji - Mathematics and Sensibility - Wind polemicznie wobec tego wyobrażenia przypomina, że wynalazki florenckiego artysty były przede wszystkim maszynami wymyślonymi na użytek spektakli uświetniających dworskie uroczystości, reprezentowany zaś przez Leonarda: „typ myślenia nie był w ścisłym słowa znaczeniu nowoczesny i zawierał w sobie wyraźne pierwiastki średniowieczne”. Wyobraźnię Leonarda zestawia on z wyobraźnią Bernarda z Clairvaux (Wind 1952c: 706).
} 
mowania lub dawania ${ }^{8}$. W ten sposób ewidentnie reagują oni nie tyle na słowa ,jeden z was mnie zdradzi”, ile na wezwanie „bierzcie i jedzcie z tego wszyscy" (por. Mt 26,26).

Lewa strona obrazu dotyczy negatywnego aspektu daru. Warunkiem otrzymania pokarmu wiecznego życia okazuje się śmierć Chrystusa („Dla każdego jest jasne, że baranka nie można spożyć, jeśli przed spożyciem nie zostanie zabity" - powiada Grzegorz z Nyssy). Pokarm życia jest tu więc zarazem ofiara. Wind dopatruje się w chwytającej dłoni Chrystusa prefiguracji wszystkich wydarzeń, które prowadzą do Jego śmierci, w tym zdrady i pojmania. Uczniowie po tej stronie reaguja przede wszystkim smutkiem (św. Jan) lub gniewem. Zauważmy, że Wind nie twierdzi, iż motyw zdrady jest na obrazie zupełnie nieobecny, lecz przypisuje mu inną niż Goethe rangę - nie jest on głosem głównym, lecz podporządkowanym ${ }^{10}$. Wind nie pomija warstwy psychologicznej, lecz wpisuje ją w szerszy kadr - wygląd postaci oraz ich zachowanie tłumaczy obowiązująca w odrodzeniu teoria czterech temperamentów, wskazując, że każda z grup przedstawionych na obrazie reprezentuje jeden z nich. Autor podtrzymuje jednocześnie twierdzenie o prymacie teologii - wygląd i zachowanie poszczególnych uczniów podyktowane zostały przede wszystkim stosunkiem każdego z apostołów do ofiary Chrystusa: „wygląd każdej postaci wynika nie tylko z jej charakteru, lecz został także dramaturgicznie spleciony z jej reakcja na misterium Eucharystii”' (Wind 2015: 90). Toteż reakcje uczniów dodatkowo typologizuje on zgodnie z podstawowa w epoce odrodzenia zasada egzegetyczna, czyli według czterech sensów: dosłownego, moralnego, mistycznego i anagogicznego.

Podsumowując, zdaniem Winda tym, co pobudziło uczniów do żywiołowej reakcji, nie była zapowiedź zdrady, lecz paradoksalna natura Eucharystii, w której dar pokarmu życia wiecznego otrzymuje się za cenę śmierci Chrystusa ${ }^{11}$ :

\footnotetext{
${ }^{8}$ W ważnym dla Winda eseju Vischera na temat symbolu („Stan Rzeczy” 2015, nr 8, s. 17-34) autor tłumaczy, że eucharystyczne jedzenie i picie to symbole „przyjmowania” czy „przyswajania” sobie działania zbawczej śmierci ofiarnej, z której wypływa nowe życie. Komunia symbolizuje „,przyswojenie", tak jak pokarm i napój zostają całkowicie przyswojone przez ciało, przeobrażając się w jego substancję i krew.

9 Wszystkie cytaty z Pisma Świętego pochodzą z Biblii Tysiąclecia.

${ }^{10}$ Wind podkreśla, że po tej samej stronie zostały zilustrowane także inne epizody z Ostatniej Wieczerzy. Odpowiadające sobie ręce Jezusa i Judasza, sięgające do tej samej misy, ilustrują słowa „Ten, który ze mną rękę zanurza w misie, on mnie zdradzi” (Mt 26,23).

${ }_{11}$ Dialektyka śmierci i życia to jedno z „,misteriów” analizowanych przez Winda w Pagan Mysteries in the Renaissance. W pracy tej Wind zaznacza, że dla artystów odrodzenia chrześcijańskie i pogańskie misteria były wymienne - „nie widzieli żadnej trudności w zamianie poetyki pogańskiej na chrześcijańską" (Wind 1997c: 77). Książkę Winda można potraktować jako opowieść o renesansowej
} 


\section{/// 3. Leo Steinberg: wymowność form}

Dwadzieścia lat po radiowym wystąpieniu Edgara Winda obszerną rozprawę Ostatniej Wieczerzy poświęcił Leo Steinberg ${ }^{12}$. Amerykański badacz jeszcze wyraźniej niż Wind wyartykułował chęć przeciwstawienia się opinio communis panującej niemal niepodzielnie od czasów Goethego, postawiwszy sobie za cel wykazanie, że obraz jest „zarówno mniej świecki i mniej prosty", niż się powszechnie uważa (Steinberg 2001: 13). Swoją lekturę obrazu Steinberg osadził na szerokim tle dziejów jego interpretacji, traktując jako interpretacje również jego kopie i niektóre adaptacje. Wśród garstki tych, którzy wyłamali się z chóru wtórującego Goetheańskiej formule „świeckiej psychodramy", Steinberg wspomina Edgara Winda, jednak za swego prawdziwego sojusznika uznaje polskiego historyka sztuki - Jana BołozaAntoniewicza i jego wykład na temat Ostatniej Wieczerzy z $1904 \mathrm{roku}^{13}$.

Steinberg przytacza kardynalne spostrzeżenie Bołoza, że Goethe w swym eseju wcale nie opisywał obrazu z refektarza kościoła Santa Maria delle Grazie. Wprawdzie widział go, przejeżdżając przez Mediolan w 1788 roku, jednak przygotowując swój słynny szkic trzydzieści lat później, miał przed oczami popularny sztych Rafaela Morghena (il. 1) i to on stał się przedmiotem jego interpretacji. Problem w tym, że na sztychu Morghena „zatarte zostało wszystko to, co nacechowane znaczeniem i co niezbędne dla interpretacji dzieła Leonarda" (Bołoz-Antoniewicz 2013: 176).

Dla Bołoza centralną postacią obrazu jest Chrystus. W ten sposób zaprzeczył on twierdzeniu Goethego, że został On ukazany jako postać „wycofana", która swym milczeniem zaledwie przytakuje wypowiedzianym wcześniej słowom o zdradzie. Skazując Chrystusa na bierność, Goethe przesunął ciężar narracji na uczniów, a tymczasem zgodnie z poglądami teoretycznymi samego malarza oraz zgodnie z narracją mediolańskiego obrazu tematem kompozycji malarskiej jest zawsze działanie, którego podmiotem jest postać centralna: „Chrystusa nie cechuje [...] martwota czy pasywność, ale stanowi On rzucający się w oczy, organicznie ożywiony punkt

\footnotetext{
konkordancji czy „utajonym powinowactwie między pogańskim i biblijnym objawieniem” (Wind 1997a: 109).

12 Por. Steinberg 1973: 297-410. Rozszerzona wersja książkowa Leonardo's Incessant Last Supper ukazała się w 2001 roku. Po raz pierwszy swoje poglądy na temat Ostatniej Wieczerzy Steinberg przedstawił w wykładzie w 1966 roku.

${ }^{13}$ Streszczenie tego wykładu wygłoszonego na posiedzeniu krakowskiej Akademii Umiejętności pt. Das Abendmabl Lionardos opublikował „Bulletin de l'Académie des Sciences de Cracovie”, juin 1904, s. 53-66. Steinberg przedrukowal je w swojej pracy wraz z angielskim przekładem (Steinberg 2001: 200-216). Przekład polski Ostatnia Wieczerza Leonarda da Vinci, tłum. M. Bryl, „Artium Quaestiones”, nr XXIII, 2013, s. 175-186. Na temat Bołoza zob. m.in. Bryl 2011, Rzepińska 1972.
} 


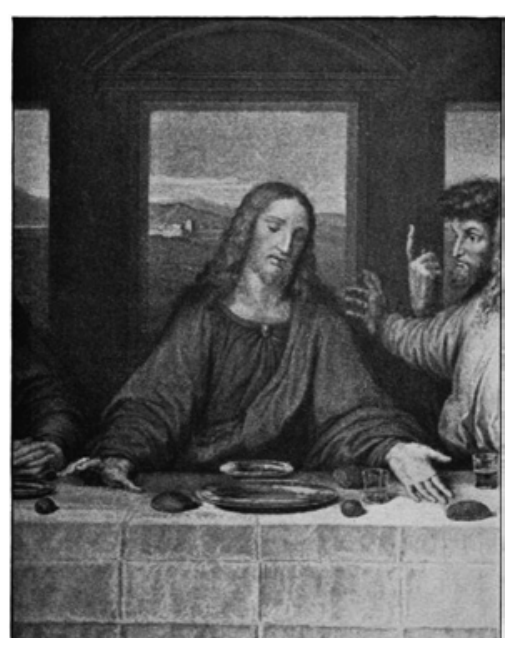

Il. 1. Rafael Morghen, sztych według Ostatniej Wieczerzy Leonarda.

całego obrazu. Chrystus na tym wyjątkowym obrazie nie jest milczącym, mimicznym refleksem własnych słów, ale determinującym organizatorem całości, także tutaj jest On «źródłem życia»" (Bołoz-Antoniewicz 2013: 178).

Działanie Chrystusa wyraża się m.in. w układzie Jego rąk: „Obie ręce rozchodzą się wyraźnie zaznaczonymi liniami, niczym dwaj gońcy posłani w różnych kierunkach; lewa ręka jest dość napięta i wyciąnnięta, lewa dłoń otwiera się pełną powierzchnią wyraźnie coś wskazującym, «mówiącym» ruchem; natomiast prawa dłoń wysuwa się do przodu, z powierzchnia skierowaną w dół, z rozczapierzonymi, pająkowatymi palcami, gotowa do uchwycenia lub ujęcia jakiegoś przedmiotu. Oczy, spoglądając w kierunku wskazanym przez lewicę, dosięgaja przedmiotu znajdującego się na linii spojrzenia” (Bołoz-Antoniewicz 2013: 177). Mówiąc najkrócej, Chrystus zdaniem Bołoza jedną ręką wskazuje na leżący na stole chleb, drugą sięga po stojace na stole wino. Obecność symboli eucharystycznych ma dla tej wykładni znaczenie podstawowe, toteż wśród wielu mankamentów sztychu Morghena polski historyk wymienia pominięcie kielicha z winem, po który na obrazie Leonarda sięga Chrystus (il. 2).

Steinberg podejmuje tę interpretację, która - choć rzadko przywoływana w literaturze przedmiotu - w jego mniemaniu zasługuje na miano jednego z „najśmielszych aktów rewizjonizmu w dziejach historii sztuki” (Steinberg 2001: 200-201). Rewizjonizm Bołoza polegał nie tylko na buncie wobec autorytetu słowa poety, ale przede wszystkim na afirmacji autorytetu samego wizerunku. Za przełomowa w wykładni Bołoza Steinberg uznaje przyjętą przezeń metodologię, a mianowicie to, że podjął on „pionierska próbę ulokowania znaczenia tego dzieła w jego strukturze formalnej” (Steinberg 2001: 203). Istotnie, swój wniosek na temat zarówno aktywnej postawy Leonardowego Chrystusa, jak i znaczenia obrazu jako całości Bołoz wyprowadził z analizy sposobu padania światła i struktury przestrzennej obrazu. To one są w jego oczach głównymi środkami komunikacji znaczenia - to one, a nie znajomość odrodzeniowych teorii egzegezy biblijnej czy dawnych teorii psychologicznych, doprowadziły polskiego historyka do 
wniosku, że Jezus Leonarda już wcześniej musiał wypowiedzieć słowa ,jeden z was mnie zdradzi”, a malowidło przedstawia kolejny epizod z ewangelicznej narracji, a mianowicie ten, w którym sięgając po wino, miał On wypowiedzieć słowa: „bierzcie i pijcie z niego wszyscy”. To w strukturze formalnej obrazu zakodowany jest komunikat, że tematem kompozycji jest ustanowienie Eucharystii (Bołoz-Antoniewicz 1904: 66).

Także Steinberg poszukuje znaczenia Ostatniej Wieczerzy w strukturze formalnej dzieła. Jeszcze obszerniej i dokładniej niż Bołoz rekonstruuje „wymowność form”14 - właściwy język, jakim przemawiają obrazy. Jednocześnie świadomie odcina się od tradycji ikonologicznej, która do głębokich znaczeń obrazu chce docierać droga analizy jego kulturowego kontekstu, zwłaszcza źródeł pisanych, których obraz mógłby być ilustracją. W oczach Steinberga takie podejście równa się nieuprawnionemu podporządkowywaniu obrazów tekstom.

W jednej z wcześniejszych prac Steinberg stwierdza, że za porażkę uznałby, ,gdyby ktoś chciał potraktować [...] dzieła [sztuki] jako ilustracje jakichś tekstów lub argumentów [podkr. RP] teologicznych. Wręcz przeciwnie: obrazy ukazują coś, czego zapewne nikt nigdy nie wyraził słowami. One same pełnią funkcję tekstów źródłowych” (Steinberg 2013: 26). W stwierdzeniu tym daje jasno do zrozumienia, że odrzuca metodę ikonologiczną, zarówno w wersji zaproponowanej przez Erwina Panofskiego, jak i tej, której zwolennikiem był Edgar Wind. Ten drugi powtarzał bowiem, że wbrew potocznym wyobrażeniom metoda ikonologiczna nie polega na poszukiwaniu passusów, które „pasuja” do danego obrazu czy których obraz miałby być dosłowną ilustracja (por. Wind 2015b: 77-81), lecz na objaśnianiu ucieleśnionych w obrazie idei. Tłumaczył, że punktem wyjścia ikonologii jest historyczny fakt, że dzieła sztuki renesansowej były zamawiane przez zleceniodawców, ażeby komunikować pewne treści czy idee $^{15}$. Renesansowi artyści odznaczali się przenikliwym talentem do ich wizualizacji, jednak nie wymyślali tych koncepcji samodzielnie. Program obrazu powstawał w rozmowach ze zleceniodawcami, a gdy zleceniodawcą była strona kościelna, artysta miewał niekiedy teologicznego doradcę. Renesansowy artysta musiał dobrze rozumieć idee, które mial przedstawić, jednak niekoniecznie poznawal je dzięki lekturze uczonych dzieł: dla

\footnotetext{
${ }^{14}$ Kategorię ,wymowności form” Steinberg stosuje już w swojej pracy doktorskiej na temat koncepcji architektonicznej Il Carlino Borrominiego (Il Carlino Borromini's San Carlo Alle Quattro Fontane. A Study in Multiple Form and Architectural Symbolism) z 1960 roku, w której podejmuje próbę wyczytania z form budynku jego przesłania teologicznego.

${ }^{15}$ Wbrew współczesnej pogardzie dla sztuki dydaktycznej - dawniej taka była bardzo często jej główna funkcja, zob. także Wind 1963: 48-52.
} 
ówczesnych artystów głównym kanałem transmisji wiedzy były z reguły „uczone rozmowy"16.

Wind upatruje zadania historyka sztuki w rekonstrukcji treści obrazów, a konkretnie w odsłanianiu sensu zapomnianych czy częściowo zrozumiałych symboli. Celem ikonologii winno być ich „oczyszczenie”, sprawiające, żeby owe symbole ponownie przemówiły. W tym celu ikonolog potrzebuje tekstów. Szuka w nich jednak nie konkretnych passusów, lecz obiegowych teorii teologicznych, filozoficznych czy politycznych pozwalających zrozumieć symbole $i$ ich przesłanie. Oddala się on zatem od obrazu, ale po to, aby móc się do obrazu lepiej zbliżyć. „Nasza lektura - powiada Wind - musi zaprowadzić nas bardzo daleko od obrazu, po to żeby poprawnie przywieść do niego z powrotem" (Wind 2015b: 79). Chce przez to powiedzieć, że droga okrężna ikonologii jest jedyna, która gwarantuje rzeczywiste zbliżenie się do obrazu.

Bliższy stanowisku formalistów ${ }^{17}$ Steinberg opowiada się za bezpośrednim podejściem do obrazu, tj. bez zapośredniczenia w tekstach pisanych, tłumacząc, że obraz sam w sobie jest „tekstem źródłowym”. Należy do interpretatorów, którzy proponują skupić całą uwagę na tym, „co dzieło sztuki samo przez się wydobywa na jaw" (Bätschmann, cyt. za Bryl 2008: 435), tymczasem źródła pisane tę uwagę skutecznie odwracaja. W postawie ikonologów dostrzega dziedzictwo dawnej i głęboko zakorzenionej nieufności wobec wizerunków, których istotową słabość próbują przezwyciężać, udzielając im „zewnętrznego” wsparcia w postaci tekstów, dzięki którym wizerunki zyskują brakującą im jednoznaczność. Nieufność ta miała ujawnić się we wczesnej nowoczesności wraz z rosnącą dostępnością źródeł pisanych wynikającą z rozpowszechnienia się druku. Wówczas za ideał została uznana jasność, dosłowność i jednoznaczność, natomiast ambi-

${ }^{16}$ Wind wielokrotnie powtarzał, że zadaniem ikonologii (sam używał raczej określenia ,ikonografia”) jest „wychwycenie treści rozmów” - tej królewskiej drogi poznania, która była dla odrodzeniowych artystów podstawowym kanałem transmisji wiedzy (por. Wind 1997a: 114).

${ }^{17}$ Steinberg analizuje „wymowę form”, Wind - „wymowę symboli”, za czym stoją odmienne preferencje metodologiczne obu autorów. Różnicy tej nie można jednak utożsamiać z opozycją między formalizmem a podejściem treściowym. Steinberg nie był bowiem formalista, a nawet formalizm krytykował, jak tego dowodzi jego wielokrotna polemika z Clementem Greenbergiem, zob. także Hill 2014. Głosił on, że reprezentacja jest centralną estetyczną funkcją wszelkiej sztuki, także tej abstrakcyjnej (Steinberg 1953: 196). Sprawę dodatkowo komplikuje fakt, że dla niektórych historyków sztuki Steinberg przynależał do tradycji ikonologicznej. Charles Dempsey (1984) nazywa Seksualnośc Chrystusa, ,a conventional iconographic study, on the pattern of Erwin Panofsky or Edgar Wind”. Podobnie czyni Anne D’Alleva (2005: 29). Gdyby chcieć dokładniej określać przynależność metodologiczną Steinberga, to prawdopodobnie należałoby go zaliczyć do tzw. paradygmatu hermeneutycznego, który kształtował się w opozycji zarówno wobec „formalizmu”, jak i wobec ikonologii. Do paradygmatu hermeneutycznego pracę Bołoza-Antoniewicza Ostatnia Wieczerza zalicza Mariusz Bryl (2013: 174) - polski tłumacz i komentator tej rozprawy. 
walencja obrazów jawiła się jako wada i zagrożenie. Nieufność tę Steinberg nazywa „tekstyzmem”, który określa jako „wrogość wobec wszelkiej interpretacji, która zdaje się pochodzić znikąd, z tej racji, że pochodzi z obrazów" (Steinberg 2013: 239) ${ }^{18}$.

Edgar Wind natomiast wielokrotnie zgłaszał zastrzeżenia wobec estetyzującej i formalistycznie zorientowanej historii sztuki, odcinającej wizerunki od ich kulturowego kontekstu, zawężającej ich badanie do problemu „znawstwa” (Wind 1976) czy analiz stylistycznych, ślepych na rangę i sens omawianych dzie1 ${ }^{19}$. Sam Wind konsekwentnie niewiele uwagi poświęcał formalnej stronie omawianych wizerunków. Niekiedy stawiano mu zarzut, że zapomina, iż obrazy to także specyficzna organizacja barw i form. W swym głównym dziele - Misteriach poganskich w dobie Odrodzenia - zaledwie raz zdarzyło się mu odnieść do kwestii chromatyki, i to w celu lepszego uchwycenia sensu tego, co przedstawione (Hadot 1992: 33-34). Można przypuszczać, że w oczach swych krytyków pozostał filozofem, który w dziełach sztuki dostrzega jedynie wehikuł dla pewnych idei, a historię sztuki degraduje do rangi subdyscypliny na usługach historii myśli ${ }^{20}$.

\section{/// 4. Wind i Steinberg: ani prosty, ani jednoznaczny}

Wbrew istotnym różnicom w podejściach Winda i Steinberga odczytania Ostatniej Wieczerzy wydają się zaskakująco zbieżne ${ }^{21}$. Natomiast - wbrew metodologicznemu pokrewieństwu - Steinberg odrzucił konkluzję Bołoza, że mediolański obraz przedstawia „moment” ustanowienia Eucharystii, podobnie jak założenie, że jest on „prosty i jednoznaczny” - stwierdzeniem

\footnotetext{
${ }^{18}$ Warto dodać, że w tym samym czasie z analogicznym zjawiskiem mamy do czynienia na gruncie języka nauki i filozofii. Projekt radykalnego upojęciowienia i ideał ścisłości wiązał się z zachęta do eliminowania z języka elementów figuratywnych (metafor). „A metaphoris autem abstinendum philosopho" powiada George Berkeley (De motu, 3). Dopiero XIX-wieczne bankructwo projektu ścisłego upojęciowienia w filozofii pozwoliło na rehabilitację retoryki i metafor, w których dostrzeżono nieredukowalny i konstytutywny element naszego myślenia - także myślenia naukowego i filozoficznego. W tym samym czasie przychylniej zaczyna być postrzegana również wieloznaczność wizerunków. W ich ambiwalencji dostrzega się część tej siły, dzięki której są one w stanie wyrażać to, czego nie można powiedzieć w żaden inny sposób.

${ }^{19}$ Dla ilustracji takiego podejścia Wind przytaczał często stwierdzenie Wölfflina, że „istota stylu gotyckiego uwidacznia się równie wyraźnie w spiczastym trzewiku, jak i w katedrze" (Wind 1963: 22).

${ }^{20}$ Jeden z najsurowszych krytyków ikonologii - Otto Pächt - widzi w niej redukowanie sztuki do roli ,środka propagandy” (Pächt 1999: 72).

${ }^{21}$ Zbieżności między Windem i Steinbergiem wykraczają daleko poza interpretację Ostatniej Wieczerzy. Obaj zajmowali się głównie sztuką odrodzeniową. Dla obu ulubionym artystą był Michał Anioł. Obu intrygował teologiczny kontekst jego dzieł oraz jego predylekcja do dwuznaczności. Obaj miłość do Renesansu dzielili z zainteresowaniem sztuką współczesną, np. Picassem. Podobieństwa te można by mnożyć.
} 
tym Bołoz otwiera i kończy swoje rozważania na temat Ostatniej Wieczerzy (Bołoz-Antoniewicz 2013: 176, 185).

Dla Winda najbardziej charakterystyczną cechą mediolańskiego dzieła jest jego podwójność - rozziew między stroną prawą i lewą, między darem a utratą i poświęceniem ${ }^{22}$. Steinberg rozziew ten interpretuje szerzej - jako fundamentalną „niejednoznaczność”, przenikającą zarówno całość dzieła, jak i wszystkie jego elementy. W swej pracy amerykański historyk wskazuje na kolejne przykłady tej ambiwalencji, która w rezultacie urasta do rangi podstawowej strategii artystycznej florenckiego mistrza. Rzecz jasna, musi ona dotyczyć również figury samego Chrystusa oraz jego gestów. Toteż Steinberg zwraca uwagę, że Jego opuszczone ramiona, które w oczach Goethego wydawały się pozą rezygnacji, układają się zarazem w geometryczny trójkąt. W ten sposób w centrum malowidła znajduje się nie tylko Chrystus, ale także symbol Trójcy Świętej (Steinberg 2001: 140-141). Gdy Bołoz podkreśla, że jedna dłoń Chrystusa wskazuje na chleb, a druga sięga po kielich z winem, Steinberg precyzuje, że chleb i wino widnieja przy obu dłoniach Chrystusa (Steinberg 2001: 141, przyp. 4). Ponadto Steinberg zauważa, że siedzący Chrystus równy jest wzrostem św. Bartłomiejowi i Mateuszowi (apostołom, którzy na obrazie zostali przedstawieni w pozycji stojącej) - przewyższa On zatem wielkością wszystkich pozostałych biesiadników, tak jak ma to miejsce w malarstwie średniowiecznym. Nacechowana niejednoznacznościa jest wreszcie sama przestrzeń rozgrywającej się sceny. Stół, przy którym ulokowani są biesiadnicy, jest zbyt duży jak na pomieszczenie, w którym się znajduje, a zarazem zbyt mały, by mógł pomieścić trzynaście postaci ${ }^{23}$.

Równie ważne jest dla Steinberga to, co Wind zaledwie sugeruje, a mianowicie że obraz nie przedstawia jednego „momentu”, lecz jednocześnie ukazuje szereg epizodów z ewangelicznej opowieści, a nawet zapowiada czy prefiguruje wiele wydarzeń spoza narracji o Ostatniej Wieczerzy. Przykładowo, nóż w ręce św. Piotra każe myśleć o scenie z Ogrójca, w której apostoł odciął ucho słudze arcykapłana; załamane ręce św. Jana przypo-

\footnotetext{
${ }^{22}$ Dla porządku dodajmy, że Bołoz również wyraźnie rozróżnia w obrazie stronę lewą i prawą (2013: 184), co pozwala Steinbergowi zestawić go z Windem (Steinberg 2001: 45). W 1919 roku w czterechsetną rocznicę śmierci artysty - Bołoz wygłosił prelekcję Leonardo da Vinci (1919: 12), w której powiada: Ostatnia Wieczerza to „najwyższy jak dotąd wyraz obcowania bóstwa z człowiekiem oraz boskiej miłości [...] z motywem podwójnym - jednym przebrzmiewającej już zapowiedzi zdrady i drugim nie mniej jasnym i niedwuznacznym ustanowienia sakramentu ołtarza, z tak widocznie przedstawionym gestem ręki, wyciąniętej ku chlebowi: «Oto ciało moje»”.

${ }^{23}$ Wrażenie to było jedną z przyczyn awersji Berensona do Ostatniej Wieczeræy, który o postaciach na obrazie napisał: „I remember feeling that they were too big, and there were too many of them in the room" (Berenson 1916: 1).
} 
minaja gest, z którym tradycyjnie wyobrażano umiłowanego ucznia Chrystusa pod krzyżem. Wszystko to czyni narrację obrazu wysoce nielinearna, stanowiącą monumentalną summę wielu epizodów wydarzeń wielkanocnych skondensowaną w jednym obrazie. Prostota i klarowność to zatem ostatnie rzeczy, jakie można by o nim orzec.

Znaczenie jednoczesności dla obrazu Leonarda Steinberg wywodzi z rozważań teoretycznych samego artysty. W Paragone Leonardo dostrzega wyższość malarstwa nad poezją i innymi sztukami właśnie w tym, że potrafi ono jednocześnie ukazać to, co poezja musi mozolnie opisywać krok po kroku ${ }^{24}$. Natomiast dla głównej ambiwalencji dzieła, jaką jest to, że można je odczytywać zarazem w kluczu daru Eucharystii, jak i w kluczu zdrady i śmierci, Steinberg podaje uzasadnienie teologicznie. Odpowiada za nie „niejednoznaczność” postaci samego Chrystusa, który zgodnie z nauką chrześcijańską ma podwójną naturę: ludzką i boską. Owa „podwójna natura zostaje wyrażona w postaci dwóch wydarzeń tamtej nocy: ogłoszenia zdrady, które zapowiada Jego śmierć, i ustanowienia Eucharystii, które wywodzi się z Jego boskości” (Steinberg 2001: 57).

\section{/// 5. Wind i Steinberg: nie świecki}

Steinberg nie kryl, że obszerna panorama dziejów recepcji mediolańskiego obrazu miała służyć wskazaniu ogólniejszych prawidłowości. Jedną z nich była nowoczesna skłonność do fetyszyzowania jednoznaczności oraz wypieranie przez symbole werbalne bardziej wieloznacznych symboli wizualnych. Inna pokazanie na konkretnym przykładzie zjawiska eliminowania $z$ interpretacji sztuki renesansowej konotacji religijnych. Pomijanie symboliki eucharystycznej i skupianie się wyłącznie na dramacie zdrady czy przeoczanie przez kopistów obrazu stojącego przed Jezusem kielicha z winem to przykłady „zubożenia treści”, które jest „dziedzictwem wieku Oświecenia” (Steinberg 2001: 31). Czyniono tak w przekonaniu że „powołaniem doskonałej sztuki jest objawiać wyłącznie ludzkie prawdy, a pośrednictwo religii może od prawd tych jedynie odwodzić lub je wypaczać” (Steinberg 2001: 13).

\footnotetext{
${ }^{24}$ W słynnym fragmencie Paragone Leonardo pisał: „Twoje pióro wyczerpie się, zanim opiszesz w pełni to, co malarz za pomocą swej umiejętności przedstawi ci bezpośrednio. I język twój będzie zmorzony pragnieniem, a ciało sennością i głodem pierwej, zanim przedstawisz słowami to, co malarz przedstawi ci w jednej chwili. [...] Jak długie i niezmiernie nużące byłoby w poezji opowiadanie o wszystkich ruchach uczestników, [...] o wszystkim, co z wielką zwięzłością i prawdą ukazuje ci malarstwo" (da Vinci 1953: 15).
} 
Steinberg dostrzega wyraźny związek między fetyszyzowaniem jednoznaczności a sekularyzującym zubożeniem treści. To w ramach ideału jednoznaczności trzeba było pominąć bosko-ludzką ambiwalencję Chrystusa, a wraz z nią wykluczyć możliwość, żeby doskonała sztuka objawiała ludzkie prawdy również za pośrednictwem tematów religijnych. W ostatecznym rachunku Steinberg twierdzi, że nowoczesne ujednoznacznienie i wiążący się z nim sekularyzm głęboko utrudniły dostęp nie tylko do mediolańskiego obrazu Leonarda, ale do sztuki odrodzeniowej w ogóle.

Nie jest to u Steinberga konkluzja nowa. Jeszcze dobitniej amerykański badacz artykułuje ją w swej wcześniejszej pracy The Sexuality of Christ in Renaissance Art and in Modern Oblivion, której tematem była zmiana w sposobie przedstawiania Chrystusa w sztuce Renesansu ${ }^{25}$. O ile w tradycji bizantyńskiej i w średniowiecznej sztuce włoskiej dzieciątko Jezus przedstawiano w luźnych szatach, o tyle począwszy od wieku XIV zaczęto Je coraz powszechniej wyobrażać jako częściowo lub całkowicie nagie. W nagości tej zazwyczaj dopatrywano się przejawu renesansowego naturalizmu, zrodzonego z naśladowania wzorów antycznych, a także zapowiedzi nowoczesnej świeckości. Steinberg przeczy, by tak fundamentalna zmiana konwencji mogła być podyktowana wyłącznie względami estetycznymi, i sugeruje, że musiała ona mieć związek z teologia, a dokładnie z ważnym przesunięciem akcentów, które dokonało się na gruncie odrodzeniowej myśli teologicznej. Odrodzeniowa teologia mianowicie zdecydowanie większe niż dotychczas znaczenie przypisała faktowi Wcielenia. Głosiła pogląd, że ludzkość nie została zbawiona dopiero wraz ze śmiercią i zmartwychwstaniem Chrystusa, ale potencjalnie została ona odkupiona już w momencie przyjęcia przez Boga ludzkiego ciała. Innymi słowy, Wcielenie odczytano wówczas jako fundamentalną nobilitację człowieka oraz jego cielesności, jako wyniesienie ludzkiej natury (Steinberg 2013: 14-15, por. Kalinowski 1997: 118).

Przed sztuką odrodzeniową stanęło zadanie wyrażenia nowej teologicznej intuicji, różniącej się od tej, która przyświecała sztuce chrześcijańskiej poprzednich epok - akcentującej przede wszystkim boskość Chrystusa (czemu miało służyć m.in. ukazywanie Chrystusa w formach hieratycznych, bardzo często zapożyczonych z wzorów cesarskich) ${ }^{26}$. Toteż sednem teologii artystów Odrodzenia stało się uczłowieczenie Boga. Sztuka odrodzeniowa celebrowa-

\footnotetext{
${ }^{25}$ Po raz pierwszy opublikowana jako tom pisma „October”, nr 25, 1983. Wydanie rozszerzone: Chicago 1996. Tłum. polskie: Seksualnośc Chrystusa. Zapomniany temat sætuki renesansowej, tłum. M. Salwa, Kraków 2013.

${ }^{26} \mathrm{Na}$ temat trudności, z jakimi borykała się sztuka chrześcijańska w wyrażeniu podwójności natury Chrystusa, oraz o inspiracji, jaka przy tej okazji czerpała z cesarskich form wizualnych, zob. także Kantorowicz 1947.
} 
ła fakt Wcielenia, ukazując zwykłe ludzkie ciało Chrystusa, przedstawiając Go jako niemowlę, w scenach karmienia czy eksponując Jego płciowość. Steinberg dochodzi do wniosku, że powszechnie znane odrodzeniowe zainteresowanie ludzkim ciałem nie wynikało z zaniku wiary religijnej czy imitacji antycznych wzorców, lecz było konsekwencja przesłania teologicznego. Sztuce tej udało się mianowicie trafnie wyartykułować chrześcijańska naukę o cielesnym uczłowieczeniu Boga, przez co zasługuje ona na miano „pierwszej i ostatniej fazy sztuki chrześcijańskiej, która może twierdzić, iż odpowiada chrześcijańskiej ortodoksji” (Steinberg 2013: 79)27.

Wraz z nowoczesną tendencją do ujednoznaczniania sensu owa podwójność natury Chrystusa uległa zapomnieniu. Steinberg formułuje wręcz oskarżenie pod adresem nowoczesności i jej amnezji ${ }^{28}$, rozdzielającej boskość i ludzkość oraz deprecjonującej człowieczeństwo Chrystusa, co m.in. znajdowało wyraz w zakrywaniu Jego nagości. Swoje zadanie w tej pracy Steinberg definiuje jako przywrócenie pamięci i odzyskanie jednoczesności tego, co boskie i ludzkie. W tym celu postuluje nowy sposób patrzenia lub raczej rekonstrukcję tego punktu widzenia, z którego ówczesny widz oglądał odrodzeniowe obrazy. Tylko w ten sposób możemy dotrzeć do prawdziwej natury sztuki odrodzeniowej (Steinberg 2013). W podobny sposób Steinberg formułuje swój cel w odniesieniu do Ostatniej Wieczerzy: „Naszym zadaniem jest obwieścić, jak dzieło to wygląda w epoce, która nie upiera się już przy traktowaniu Odrodzenia jako tryumfalnego pochodu sekularyzmu" (Steinberg 2001: 14). Ambicja badacza jest zatem dojść do postsekularnego spojrzenia na dzieło Leonarda, które na powrót uwzględni jednoczesność obu perspektyw.

Bez wattpienia prawdziwym sojusznikiem Steinberga w dziele przywracania znaczenia renesansowej teologii dla odbioru sztuki odrodzeniowej był Edgar Wind. W związku z pracami nad twórczością Michała Anioła, już w latach 30. ubiegłego stulecia, Wind prowadził intensywne studia nad - całkowicie niezbadaną w tamtym czasie - odrodzeniową myśla teologiczną, upatrując w niej jednego z podstawowych kontekstów twórczości florenckiego artysty. W ogłoszonej w 1944 roku rozprawie Sante Pagnini and Michelangelo. A Study of the Succession of Savonarola, poświęconej programowi fresków w Kaplicy Sykstyńskiej, Wind stwierdza, że największa przeszkoda

\footnotetext{
27 „Hieratyczne wizerunki Chrystusa znane ze sztuki bizantyńskiej lepiej pasują do gnostycznych herezji aniżeli do teologii Wcielenia” (Steinberg 2013: 77).

28 Atakowana przez Steinberga kwestia „nowoczesnego zapomnienia” pojawia się już w samym tytule dzieła: The Sexuality of Christ in Renaissance Art and in Modern Oblivion. Motyw ten gubi się w polskim przekładzie: Seksualność Chrystusa. Zapomniany temat sz̨tuki renesansowej, który sugeruje raczej, że chodzi o pewne renesansowe curiosum. Tymczasem nowoczesna amnezja dotyczy seksualności Chrystusa jako emblematu nobilitującej ludzką cielesność teologii Wcielenia.
} 
w zrozumieniu tego programu tkwi w nieznajomości renesansowej teologii: „opracowania na temat katolickiej doktryny z reguły urywaja się pod koniec Średniowiecza, w najlepszym razie zaś w połowie wieku XV, i podejmowane są na nowo dopiero po tym, jak rewolucje protestanckie dostarczyły nowego przedmiotu kontrowersji. Terra incognita pozostaje zwłaszcza myśl teologiczna z początków XVI wieku - epoki mylnie uważanej za pozbawiona teologii, choć wydała dwa najznakomitsze pomniki renesansowej teologii, jakimi są Kaplica Sykstyńska i Dysputa" (Wind 1944: 211) ${ }^{29}$. Jego studia nad symboliką religijna Michała Anioła ${ }^{30}$ zawierają zarazem prekursorskie dociekania na temat specyfiki renesansowej teologii, która doczekała się systematycznego opracowania dopiero trzydzieści lat później. Ich beneficjentem był już Leo Steinberg.

Wind zwracał uwagę, że teologia ta, nawiązując do tradycji Ojców Kościoła, zwłaszcza Orygenesa, świadomie dystansowała się od arystotelesowskiej scholastyki (Wind 1954) i rozwijała się nie tyle w uczonych summach czy traktatach, ile w homiliach. Nie ma też wątpliwości, że kres jej rozwojowi położyła reformacja, a jednym ze skutków było odrzucenie klasycznej doktryny czterech sensów Biblii na rzecz znaczenia dosłownego. W 1938 roku Wind pisze: „wraz ze wzrastającym naciskiem kładzionym przez protestantów na dosłowne rozumienie Biblii luterańscy doktorzy uznali wykładnię alegoryczną, moralną i anagogiczną za niedopuszczalne urojenie wyobraźni" (Wind 1938: 64). Krok ten prawdopodobnie nie pozostał bez wpływu na przyszłe cenzurowanie języka figuratywnego również na gruncie filozofii.

Wind nie feruje oskarżeń pod adresem nowoczesności i w odróżnieniu od Steinberga nie nadaje się na herolda postmodernizmu. Jednak i on podkreśla „nieustająca potrzebę odzyskiwania utraconych sposobów percepcji” (Wind 1963: 61). Dystans czasowy dzielący nas od arcydzieł Renesansu oraz zawiłość symboli, jakimi częstokroć się one posługują, sprawia, że dla ich zrozumienia nie wystarcza samo wczytywanie się w język form. „Jeśli dzieła, których «tematy» popadły w zapomnienie, mają odzyskać estetyczny blask, potrzeba rewindykować ogromne połacie faktograficznej erudy-

\footnotetext{
${ }^{29}$ Interdyscyplinarne podejście Winda, w którym na równych prawach omawiał on również zagadnienia teologiczne, nierzadko spotykało się z silnym oporem. W jednym z listów wspomina, że po wykładach na temat sztuki renesansowej na Uniwersytecie w Chicago na poczattku lat 40. „publicznie został nazwany obskurantem” (cyt. za Sears 2000: XXXIX, przyp. 52). W rezultacie zrezygnował z pracy na tym uniwersytecie.

${ }^{30}$ Studia te zostały zebrane w wydanym pośmiertnie tomie The Religious Symbolism of Michelangelo: The Sistine Ceiling, red. E. Sears, Oxford 2000. Zbiór poprzedzony jest wstępem znawcy teologii odrodzeniowej Johna O’Malleya, który jest również autorem ważnej wypowiedzi na temat Seksualności Chrystusa Steinberga. Wypowiedź O’Malleya Steinberg włączył jako postscriptum do drugiego wydania swojej pracy (2013: 230-234).
} 
cji uzyskiwanej drogą złożonych studiów historycznych" (Wind 1963: 61). Innymi słowy, żeby dzieła te przemówiły do dzisiejszego odbiorcy, trzeba podejść do nich drogą okrężną, wiodąca przez meandry dawnych doktryn filozoficznych, teologicznych, literackich i politycznych.

Skąq jednak bierze się ta potrzeba przywracania im wymowności? Otóż Wind nie zgadza się z opinia, jakoby „każde arcydzieło było bezpieczne w swojej nieśmiertelności" (Wind 1963: 62). Historia zna wystarczająco wiele przykładów nietrwałości tego, co w minionej epoce uchodziło za „arcydzieło”. Co ważniejsze, nie jest „bezpieczna w swej nieśmiertelności” sama sztuka. Niemiecki historyk nader poważnie potraktował opinię Hegla z Wyktadów o estetyce:

Duch naszego dzisiejszego świata [...] przekracza już i przewyższa szczebel, na którym sztuka stanowi najwyższy sposób uświadomienia sobie absolutu. Swoista forma, jaką stanowi twórczość artystyczna i jej dzieła, nie zaspokaja już naszych najwyższych potrzeb. Wyrośliśmy już z tego, byśmy mogli dziełom sztuki oddawać cześć boska i modlić się do nich. [...] Myśl i refleksja prześcignęły sztukę piękną. [...] Dlatego nasza obecna epoka w całokształcie swych stosunków nie jest okresem sprzyjającym sztuce (Hegel 1964: 19-20).

oraz

można wprawdzie żywić nadzieję, że sztuka będzie coraz wyżej wznosić się i doskonalić, ale forma jej przestała już być najwyższą potrzebą ducha. Chociażbyśmy nawet figury bogów greckich uważali za szczyt doskonałości, a obrazom Boga Ojca, Chrystusa, Marii przyznawali największą wzniosłość, na nic się to nie zda, nie zginamy już dziś kolan przed nimi (tamże: 174) ${ }^{31}$.

Hegel sugeruje tu, że choć sztuka w naszych czasach nadal zdaje się bujnie rozwijać, to od dawna czyni to na obrzeżach nowoczesnego życia, jako że centralne miejsce przypadło w nim nauce. Proces ten uwidacznia się np. w tym, że sztuka przestała być dzisiaj „groźna” i mało kto odczuwa przed nią ów „zbożny lęk”, który kiedyś skłonił Platona do sformułowania

\footnotetext{
31 Wind cytuje ten passus Hegla już w swojej wczesnej pracy Theios Phobos: Untersuchungen über die platonische Kunstphilosopbie, „Zeitschrift für Ästhetikund Allgemeine Kunstwissenschaft” XXVI, 1932, s. 396. Powołuje się na niego w szkicu Traditional Religion and Modern Art z roku 1952 (przedruk w: Wind 1983: 96), a wreszcie omawia go w wykładach z roku 1960, ogłoszonych drukiem jako Art and Anarchy (1963: 9-10 oraz s. 100 przyp. 17).
} 
postulatu objęcia jej surową cenzurą. Dzisiejszej sztuce pozostało co najwyżej bycie „interesująca” (Wind 1963: 10). Przemieszczanie się sztuki na margines współczesnej kultury jest po części niezawinione, gdyż wynika ze zmian strukturalnych. Po części jednak wiąże się z tendencjami występującymi w samej sztuce, zwłaszcza z jej aspiracją do pełnej autonomii, „czystej percepcji”, wyrażania jedynie samej siebie. W procesie tym sekundowała jej historia sztuki, która dążąc do suwerenności dyscypliny, faworyzowała podejście formalistyczne.

Teraz wyraźniej widać, z czego wynika Windowska awersja do formalizmu, jak również jego teologiczna predylekcja. Losy sztuki w dobie Odrodzenia dostarczają wymownego przykładu, jak jej zależność mogła iść w parze z wysoka rangą kulturowa, podczas gdy współczesna autonomia sztuki wiąże się z postępującą utratą znaczenia. Słabość ukierunkowanych estetycznie badań nad sztuką wynika nie tylko stąd, że te nie oddają sprawiedliwości sztuce odrodzeniowej, ale także z tego, że nie są w stanie przeciwstawić się dzisiejszemu jej dryfowaniu na coraz odleglejszy margines. Gdy w Misteriach pogańskich $w$ dobie Odrodz̨enia Wind deklaruje, że jego celem będzie „naświetlenie pewnej liczby wielkich dzieł sztuki Odrodzenia” (Wind 1997a: 104), kiedy obiecuje usuwać zasłonę niejasności spowijająca nieczytelne dziś malarskie symbole, to czyni to w przekonaniu, że pogłębione rozumienie tych dzieł wspomaga ich odbiór i chroni ich współczesna doniosłość. Skoro „nasze oko widzi to, co czyta umysł” (Wind 1963: 60), to wiedza ta nie tylko nie przekreśla wraźliwości estetycznej, lecz stanowi warunek wszelkiego sensownego widzenia. Trawestując powiedzenie Edwarda Morgana Forstera, Wind wielokrotnie powtarzal, że wielki symbol czy dzieło sztuki jest przeciwieństwem Sfinksa - ożywa dopiero, gdy rozwikła się jego zagadkę (por. Wind 1950: 350, Wind 1958: 235). Wszystkie uczone dekryptaże symboli w ostatecznym rachunku służą pogłębieniu naszych doznań estetycznych. „Istnieje jeden - i tylko jeden - sprawdzian artystycznej wartości wszelkiej interpretacji: musi ona wyostrzyć nasz odbiór dzieła i w ten sposób zwiększać naszą estetyczna przyjemność" (Wind 1963: 62, Wind 1997a: 105). W wydobyciu teologicznego rdzenia Ostatniej Wieczerzy gra toczy się o siłę estetycznego wrażenia, jakie obraz ten może nadal wywierać.

\section{/// 6. Zakończenie}

Edgar Wind i Leo Steinberg - dwaj badacze sztuki - odmiennymi drogami doszli do zaskakująco komplementarnego odczytania Ostatniej Wiecze- 
ræy Leonarda da Vinci, w jej centrum odnajdując główne misterium chrześcijańskiego kultu. Prawdziwym motywem tego antysekularnego frontu, jaki zawiązał się między nimi, nie była jednak religia, lecz obrona wiary w sztukę.

Bibliografia:

/// Berenson B. 1916. The Study and Criticism of Italian Art, Bell, London.

/// Bołoz-Antoniewicz J. 1904. Das Abendmabl Lionardos, „Bulletin de l'Académie des Sciences de Cracovie", nr 6, s. 53-66. (Tłum. polskie: Ostatnia wieczerza Leonarda da Vinci, tłum. M. Bryl, „Artium Quaestiones” 2013, nr XXIV, s. 175-186.)

/// Bołoz-Antoniewicz J. 1919. Leonardo da Vinci w cąterechsetna rocznice śmierci artysty, Lwów.

/// Bossi G. 1810. Del Cenacolo di Leonardo da Vinci libri quattro, Milano [reprint].

/// Bryl M. 2008. Sumerenność dyscypliny. Polemicz̨na bistoria bistorii sz̨tuki od 1970 roku, Wydawnictwo Naukowe Uniwersytetu im. Adama Mickiewicza, Poznań.

/// Bryl M. 2011. Jan Bołoz-Antoniewicz. (1858-1922), „Rocznik Historii Sztuki", nr XXXVI, s. 7-20.

/// Bryl M. 2013. Botoz - Leonardo - Ikonika. Uwagi ttumacza, „Artium Quaestiones”, nr XXIV, s. 173-174.

/// Burckhardt J. 1992. On Leonardo’s Last Supper, „Achademia Leonardi Vinci”, nr 5, s. 114-116.

/// Clark K. 1964. Leonardo da Vinci, tłum. K. Jurasz-Dąbska, Arkady, Warszawa.

/// Creighton G. 1984. Edgar Wind as Man and Thinker, „The New Criterion", nr 7, s. 36-41.

/// D’Alleva A. 2008. Metody i teorie historii sz̧tuki, tłum. E. Jedlińska, J. Jedliński, Universitas, Kraków.

/// Dempsey Ch. 1984. Christ Made Male, „The New Criterion”, nr 3, s. $71-76$. 
/// Dvořák M. 1974. Późniejsze dzieła Leonarda, [w:] tegoż, Max Dvorák i jego teoria driejón sz̨tuki, tłum. L. Kalinowski, Państwowe Wydawnictwo Naukowe, Warszawa, s. 382-409.

/// Goethe J.W. 1817. Joseph Bossi über Leonards da Vinci Abendmabl zu Mailand, [w:] L. Mazzucchetti, Goethe e il Cenacolo di Leonardo, Milano 1939, s. 49-84.

/// Goethe J.W. 1980. Podróż włoska, tłum. Z. Herz, Państwowy Instytut Wydawniczy, Warszawa.

/// Gombrich E.H. 1993. Papergiven on the Occasion of the Dedication of The Last Supper (after Leonardo), „Magdalen College Occasional Paper”, nr 1, s. 7-19.

/// Hadot P. 1992. Métaphysique et Images, „Préfaces”, s. 33-37.

/// Hegel G.W.F. 1964. Wykłady o estetyce, t. 1, tłum. J. Grabowski i A. Landman, Państwowe Wydawnictwo Naukowe, Warszawa.

/// Hill M. 2014. Leo Steinberg vs Clement Greenberg, 1952-72, „Australian and New Zealand Journal of Art", nr 1, s. 21-29.

/// Kalinowski L. 1997. Jesz̧cze do odkrycia, „Znak”, nr 5, s. 116-119.

/// Kantorowicz E.H. 1947. The Quinity of Winchester, „The Art Bulletin”, nr 1, s. 73-85.

/// Kasperowicz R. 1997. Cay Leonardo da Vinci byt zlym malarz̧em?, „Znak”, nr 5, s. 69-83.

/// Koerner J.L. 2004. Leonardo's Incessant Last Supper, „The Art Bulletin”, vol. 86 , no. 4, s. 777-783.

/// Leonardo da Vinci. 1953. Paragone, tłum. M. Rzepińska, Zakład Narodowy im. Ossolińskich, Wrocław.

/// Levi-Strauss D. 1997. Rescuing Art From Modern Oblivion, „The Wilson Quarterly", nr 3, s. 34-49.

/// Mikołajewski J. 2014. Tajemnice Ostatniej Wieczerzy, „Gazeta Wyborcza”, nr 19/04/2014.

/// Nicholl C. 2006. Leonardo da Vinci. Lot wyobraźni, tłum. M. i A. Grabowscy, Wydawnictwo W.A.B., Warszawa.

/// O'Malley J.W. 2000. The Religious and Theological Culture of Michelangelo's Rome, 1508-1512, [w:] E. Wind, The Religious Symbolism of Michelangelo. The Sistine Ceiling, red. E. Sears, Oxford University Press, Oxford, s. XLI-LII. 
/// O’Malley J.W. 2013. Postcriptum, [w:] L. Steinberg, Seksualność Chrystusa. Zapomniany temat sztuki renesansowej, tłum. M. Salwa, Universitas, Kraków s. $230-234$.

/// Pater W. 1998. Leonardo da Vinci, [w:] tegoż, Renesans. Rozważania o sztuce i poezji, tłum. P. Kopszak, Wydawnictwo Aletheia, Warszawa, s. 109-114.

/// Pächt O. 1999. The Practice of Art History. Reflections on Method, Brepols Publishers, London.

/// Phillips D. 2011. Leo Steinberg's Artistic Vision, „The First Things”, December, s. 35-39.

/// Rurner A.R. 1994. Inventing Leonardo, University of California Press, New York.

/// Rzepińska M. 1972. Znajomość Leonarda w Polsce, „Biuletyn Historii Sztuki”, nr 34, s. 222-226.

/// Séailles G. 2007. Leonardo da Vinci, tłum. M. Czekanowska, Firma Księgarska Jacek i Krzysztof Olesiejuk, Ostrów Mazowiecka.

/// Sears E. 2000. Edgar Wind on Michelangelo, [w:] E. Wind, The Religious Symbolism of Michelangelo. The Sistine Ceiling, red. E. Sears, Oxford University Press, Oxford, s. XVII-XL.

/// Simmel G. 2006. Ostatnia wieczerza Leonarda da Vinci, [w:] tegoż, Most $i$ drz̨wi. Wybór esejów, tłum. M. Lukasiewicz, Oficyna Naukowa, Warszawa [pierwsze wydanie 1905].

/// Steinberg L. 1953. The Eye Is Part of the Mind, „Partisan Review”, nr 70, s. 194-212.

/// Steinberg L. 1973. Leonardo's Last Supper, „Art Quarterly”, nr XXXVI.

/// Steinberg L. 1977. Borromini's San Carlo alle Quattro Fontane. A Study in Multiple Form and Architectural Symbolism, Garland Publishing, New York, London.

/// Steinberg L. 2001. Leonardo's Incessant Last Supper, Zone Books, New York.

/// Steinberg L. 2013, Seksualność Chrystusa. Zapomniany temat sz̨tuki renesansowej, tłum. M. Salwa, Universitas, Kraków. 
/// Thomas B. 2015. A Short Biography of Edgar Wind, „Stan Rzeczy”, nr 8, s. 117-137.

/// Vischer F.Th. 2015. Symbol, „Stan Rzeczy”, nr 8, s. 17-34 [pierwsze wydanie Philosophische Aufsätze. Edmund Zeller zuseinsem funfzig-jährigen DoctorJubiläumgewidmet, Leipzig 1887, s. 151-193].

/// Wallis M. 1961. Malarze i miasta. Studia i sækice, Wydawnictwa Artystyczne i Filmowe, Warszawa.

/// Wind E. 1931. Warburgs Begriff der Kulturwissenschaft und seine Bedeutung für die Ästhetik, „Zeitschrift für Ästhetik und allgemeine Kunstwissenschaft”, nr 25, s. 163-179.

/// Wind E. 1932. Theios Phobos. Untersuchungen über die platonische Kunstphilosophie, „Zeitschrift für Ästhetik und Allgemeine Kunstwissenschaft”, nr XXVI, s. 349-373.

/// Wind E. 1938. A Mediaeval Formula in Kant, ,Journal of the Warburg Institute", nr I, s. 64.

/// Wind E. 1944. Sante Pagnini and Michelangelo. A study of the Succession of Savonarola, „Gazette des Beaux Arts”, 26, s. 211-246 [przedruk: Wind 2000: $1-22]$.

/// Wind E. 1950. The Eloquence of Symbols, „The Burlington Magazine”, XCII, s. 349-350.

/// Wind E. 1952a. Mathematics and Sensibility, „The Listener”, 1 maja 1952, s. 705-706.

/// Wind E. 1952b. The Last Supper, „The Listener”, 8 maja 1952, s. 747-748.

/// Wind E. 1952c. Leonardo as a Physiognomist, „The Listener”, 15 maja 1952, s. $787-788$.

/// Wind E. 1953. Traditional Religion and Modern Art. Rouault and Matisse, „Art News” 1953, nr LII, s. 18-22 [przedruk: Wind 1983: 95-102].

/// Wind E. 1954. The Revival of Origen, [w:] Studies in Art and Literature for Belle da Costa Greene, red. D. Miner, Princeton University Press, Princeton, s. 413-416 [przedruk: Wind 1983: 42-55].

/// Wind E. 1958. Pagan Mysteries in the Renaissance, W. W. Norton \& Company, London. 
/// Wind E. 1963. Art and Anarchy, Northwestern University Press, London.

/// Wind E. 1976. Krytyka znawstwa, tłum. M. Klukowa, [w:] Pojecia, problemy, metody wspótczesnej nauki o sz̨uce, red. J. Białostocki, Państwowy Instytut Wydawniczy, Warszawa, s. 170-192 [rozdział trzeci: Wind 1963: 30-46].

/// Wind E. 1983. The Eloquence of Symbols. Studies in Humanist Art, red. J. Anderson, Oxford University Press, Oxford.

/// Wind E. 1997a. Jezyk misterión i teologia poetycka, tłum. E. Wolicka, „Znak”, nr 5, s. 96-111 [fragment: Wind 1958: 1-25].

/// Wind E. 1997b. Odarcie Marsjasza, tłum. T. Żukowski, „Konteksty”, nr 3-4, s. 73-74. [fragment: Wind 1958: 171-176].

/// Wind E. 1997c. Misterium Bachiçne wedtug Michała Anioła, tłum. T. Żukowski, „Konteksty”, nr 3-4, s. 75-79 [fragment: Wind 1958: 177-190].

/// Wind E. 2000a. The Religious Symbolism of Michelangelo. The Sistine Ceiling, red. E. Sears, Oxford University Press, Oxford.

/// Wind E. 2000b. Picture and Text, [w:] Wind 2000a, s. 191-193.

/// Wind E. 2015a. „Ostatnia Wieczerza”, „Stan Rzeczy”, nr 8, s. 82-91.

/// Wind E. 2015b. Obraz, i tekst, „Stan Rzeczy”, nr 8, s. 77-81.

/// Wind E. 2015c. Wymowność symboli, „Stan Rzeczy”, nr 8, s. 70-76.

/// Wölfflin H. 1931. Sz̨tuka klasyczna, tłum. J. Muczkowski, Fundusz Kultury Narodowej, Warszawa.

\section{/// Abstrakt}

Wiosną 1952 roku Edgar Wind wygłosił dla radia BBC dwudziestominutowa pogadankę na temat Ostatniej Wieczerzy Leonarda da Vinci („The Listener", 8 May 1952). Dwadzieścia lat później obszerną rozprawę na ten sam temat opublikował Leo Steinberg („Art Quarterly” XXXVI, 1973). Każdy z autorów skonstruował swoją analizę obrazu zgodnie z przyjmowanym przez siebie rozumieniem zadań historii sztuki. Dla Edgara Winda było nim badanie symboli - odsłanianie zapomnianej lub dziś nieoczywistej ich wymowy. Leo Steinberg skupiał się przede wszystkim na wyjaśnianiu przesłania wyrażonego w języku form. Pomimo różnic podejścia w kilku 
kwestiach Wind i Steinberg byli zaskakująco zgodni: obaj odrzucili pokutujące od czasów Goethego oświeceniowe przekonanie, że w scenie Ostatniej Wieczerzy religijny temat jest zaledwie pretekstem do ukazania świeckiego w swej istocie dramatu zdrady. Obaj dostrzegli w malowidle Leonarda wyszukaną wizualną sumę chrześcijańskiej doktryny Zbawienia. Obaj starali się zrekonstruować teologiczny składnik odrodzeniowego sposobu percepcji wizerunków. Dla obu wreszcie rzeczywistym celem zwrotu ku teologii była chęć obrony godności sztuki w dobie postępującej jej marginalizacji.

Słowa kluczowe:

Edgar Wind, Leo Steinberg, Jan Bołoz-Antoniewicz, Leonardo da Vinci, Ostatnia Wieczerra, sekularyzacja

\section{/// Abstract}

In the spring of 1952 Edgar Wind gave a 20 minutes talk for radio BBC on the subject of Leonardo's Last Supper („The Listener”, 8 May 1952). Twenty years later Leo Steinberg published a sizable paper on the same topic („Art Quarterly” XXXVI, 1973). Each of the authors based his analysis of the picture according to his personal understanding of the aims of history of art. For Edgar Wind it was the examination of symbols in order to reveal their forgotten or now no longer obvious meanings. Leo Steinberg concentrated above all on clarifying the message conveyed in the language of forms. In spite of the difference of approach both authors in several important points remained surprisingly unanimous. They rejected the Enlightenment conviction, lingering since the times of Goethe, that in the scene of Last Supper the religious theme is merely a pretext to display a basically secular drama of treachery. Both perceived Leonardo's painting as an elaborate visual epitomy of Christian doctrine of Salvation. Both took pains to reconstruct the theological component of Renaissance mode of perceiving images in general. And finally for both the real objective of their turn to theology was the desire to defend the importance of art at the time of its increasing marginalization.

Keywords:

Edgar Wind, Leo Steinberg, Jan Bołoz-Antoniewicz, Leonardo da Vinci, Last Supper, secularization 